\title{
O ATAQUE ÀS ESTAÇÕES: UM EPISÓDIO DO CONTESTADO ATRAVÉS DA NARRATIVA DE ROBERT HELLING
}

\author{
ATTACK ON THE RAILWAY STATIONS: AN EPISODE FROM \\ THE CONTESTADO WAR THROUGH ROBERT HELLING'S \\ NARRATIVE
}

Márcia Janete Espig*

\begin{abstract}
Resumo: Robert Helling foi um imigrante alemão que viveu por cerca de quarenta anos na região sul do Brasil. Chegando ao país no final do século XIX, trabalhou principalmente em funções relacionadas a construção e operação de Estradas de Ferro nos estados de Santa Catarina e Paraná. Helling deixou suas memórias registradas na obra "40 Jahre im Innern von Brasilien; Erlebnisse eines Eisenbahningenieurs, von Robert Helling", (Robert Helling - 40 anos no interior do Brasil. Aventuras de um engenheiro ferroviário). Helling constituiuse como um observador privilegiado da sociedade, cultura e hábitos regionais. Além disso, descreveu importantes acontecimentos referentes ao Movimento do Contestado (1912-1916). Um dos episódios que se destaca em sua narrativa é o dos ataques às estações de São João e Calmon da Estrada de Ferro São Paulo - Rio Grande, nos quais pereceram muitos trabalhadores ligados à ferrovia, além de militares e civis. Neste artigo irei abordar o personagem Helling e analisar sua narrativa sobre o ataque às estações, relacionando-a à sociedade local e à Guerra do Contestado.
\end{abstract}

Palavras-chave: Robert Helling. Guerra do Contestado. Memórias. Imigração.

\footnotetext{
* Professora adjunta na Universidade Federal de Pelotas (UFPEL), Departamento de História e Programa de Pós-Graduação em História. E-mail: marcia.espig@terra.com.br
} 


\begin{abstract}
Robert Helling was a German immigrant who lived in the southern region of Brazil for about 40 years. When arriving in this country, at the end of the $19^{\text {th }}$ century, Helling worked mainly in functions related to construction and operation of the railways in the states of Santa Catarina and Parana. Helling left his recorded memoirs on the work " 40 Jahre im Innern von Brasilien; Erlebnisse eines Eisenbahningenieurs, von Robert Helling”, (Robert Helling - 40 years in the Brazilian inland - Adventures of a railway engineer). Helling established himself as a privileged observer of the society, culture and regional habits. Furthermore, he described important events relative to the Contestado Rebellion (1912-1916). One of these events, which are highlighted in his narratives, is the attack on the stations of Sao Joao and Calmon, in the Sao Paulo - Rio Grande Railway, in which far too many workers connected to the railway perished along with the military and civilians. In this article, I will approach Helling's character in this plot and analyze his narrative about the attack on the railway stations being related to the local community and the Contestado War.
\end{abstract}

Keywords: Robert Helling. Contestado War. Memoirs. Immigration.

Robert Helling foi um imigrante alemão que viveu por cerca de quarenta anos na região sul do Brasil. Chegando ao país no final do século XIX, trabalhou principalmente em funções relacionadas a construção e operação de Estradas de Ferro nos estados de Santa Catarina e Paraná. Helling deixou suas memórias registradas obra "40 Jahre im Innern von Brasilien; Erlebnisse eines Eisenbahningenieurs, von Robert Helling" (Robert Helling - 40 anos no interior do Brasil. Aventuras de um engenheiro ferroviário). ${ }^{1}$

Esta obra apresenta um interessante personagem, o próprio Helling. De personalidade curiosa, enérgica, metódica e aventureira, o alemão vivenciou experiências históricas que optou por relatar em sua obra. Trata-se de uma fonte primária ainda pouco explorada pela historiografia, tanto com relação à temáticas como a construção de ferrovias, a expansão capitalista de inícios do século XX e os trabalhadores nela envolvidos, quanto em relação ao movimento do Contestado (1912-1916). Neste, nosso personagem teve um envolvimento direto, e vários capítulos de seu livro dedicam-se a hábitos da região do Contestado ou a episódios referentes a este movimento social. Neste artigo irei abordar sobretudo sua descrição referente ao episódio de ataque às estações de São João e Calmon da Estrada de Ferro São Paulo - Rio Grande, nos quais pereceram muitos trabalhadores ligados à ferrovia, além de militares e civis.

O livro "40 Jahre im Innern von Brasilien; Erlebnisse eines Eisenbahningenieurs, von Robert Helling", é composto por dezesseis capítulos, distribuídos por 80 páginas. Publicada em Berlim em 1931, a obra não segue uma cronologia temporal, mas relata, ao sabor das memórias, as lembranças 
do autor referentes a hábitos, costumes, impressões ou mesmo experiências marcantes específicas, como é o caso do ataque dos rebeldes às estações da Estrada de Ferro em que trabalhava. Sofrendo o trabalho da memória, que seleciona, constrói, reconstrói e transfere, seu texto deve ser interpretado com atenção e detalhe, pois manifesta visões de mundo, imaginários, construções identitárias e de alteridade, coletiva e individualmente construídas.

A memória sofre um permanente trabalho de organização. ${ }^{2}$ Sendo seletiva, seu enunciador não deseja, e sequer poderia, dizer tudo. Sendo também um fenômeno construído, a memória recebe a influência do próprio momento em que é registrada. Distinguem-se, portanto, os relatos memorialísticos que são escritos no calor da hora daqueles organizados tempos após, na calma dos escritórios, como tudo indica ter sido o caso do texto de Helling. Neste processo a memória alcança uma reelaboração em que interferem não apenas o andamento posterior do episódio histórico relatado, mas também a (re) construção da memória, quando esta "grava, recalca, exclui, relembra". ${ }^{3}$

Sobre a biografia de Helling, pouco sabemos, além dos fragmentos por ele apresentados em seu livro. Poucas são as obras bibliográficas que se referem a este personagem e nem sempre com correção. Parcas são as fontes históricas que trazem informações sobre ele. Localiza-se ainda alguma documentação produzida pelo próprio personagem, como a troca de telegramas com o comando militar na região do Contestado. Os dados trazidos a seguir combinam informações retiradas de seu livro e da pequena quantidade de fontes bibliográficas e históricas localizadas.

Robert Helling emigrou para o Brasil em 1887, juntamente com seu irmão Georg. Cada qual trazia consigo mil marcos em ouro para eventuais compras de terra. O Vapor "Campinas", comandado pelo Capitão A. Birch, saíra do porto de Hamburgo em 19/04/1887, tendo atracado em São Francisco em 16/05/1887. Na listagem de passageiros verificamos que Robert contava então com 24 anos, tendo, portanto, nascido em 1863. Seu irmão tinha 22 anos. Ambos viajaram de $3^{\mathrm{a}}$ classe, tendo Robert se declarado operário de Berlim e Georg, lavrador. Ambos eram solteiros, protestantes e rumavam para São Bento. ${ }^{4}$ Sua origem berlinense confirma-se na narrativa, quando comenta um encontro com seu amigo Karl (com quem havia frequentado a escola) em que este o abordara "no mais perfeito dialeto de Berlim". A viagem desde a Europa até o Novo Mundo é descrita no primeiro capitulo do livro, e relata sua intenção inicial em trabalhar na lavoura. Contudo Robert Helling irá se direcionar aos trabalhos de construção e operação de Ferrovias, em um período de expansão desta modalidade de transporte em nosso país. Durante a maior parte de sua vida no Brasil Helling trabalhou na Estrada de Ferro São Paulo - Rio Grande (EFSPRG), assumindo variadas funções. ${ }^{5}$

Ainda em 1887, encontramos Robert Helling trabalhando em tarefas de medição de terrenos, em local não identificado do estado do Paraná ou Santa 
Catarina, tendo sob sua direção os filhos de vários colonos alemães, gerenciando inclusive seus salários. Embora não tenhamos detalhes de suas experiências pessoais e profissionais nos anos que se seguem a 1887, sabemos através de suas memórias que Helling trabalhou como mestre de obras na construção da Estrada de Ferro de Serrinha a Restinga Seca. Este ramal foi inaugurado em novembro de 1892. É possível, portanto, que Helling tenha iniciado os trabalhos em tarefas de ferrovias por volta de 1890 ou mesmo antes.

Em 1894 Helling era chefe de seção do trecho em operação da EFSPRG, possivelmente morando em Ponta Grossa, local que demarcava a divisão deste caminho de ferro em Linha Norte e Linha Sul. A posição assumida por Helling era importante, o que muito provavelmente significa que ele fez carreira na ferrovia durante anos. Embora não possuísse formação em engenharia, a prática e a experiência poderiam representar qualificação suficiente, visto que seu cargo era via de regra desempenhado por engenheiros formados. Sobre isso reflete um de seus comandados: "Não tinha título universitário, mas os conhecimentos profissionais trazidos da pátria e ampliados por aplicação intensiva na vida ferroviária, credenciaram-no como grande técnico em estrada de ferro". ${ }^{6}$ Talvez por este motivo Helling seja mencionado como "engenheiro" em algumas obras.

O trabalho em ferrovias marcou decisivamente a vida de Helling no Brasil. Em 1901 foi nomeado superintendente das linhas em tráfego da EFSPRG, tarefa complexa e de imensa responsabilidade. Ewaldo Krüger, ferroviário paranaense que registrou suas memórias no livro "Vencendo Rampas", menciona que vários engenheiros brasileiros declinaram o convite para esta função. Mas Helling teria sido

[...] "the right man in the right place"! A Companhia não poderia ter sido mais afortunada na escolha deste funccionario, pois que, sobre ser um homem correctissimo, tinha o dom pouco vulgar de manter entre os seus subordinados uma rigorosa disciplina e de se adaptar com facilidade ás condições do momento. Emfim, era o chefe exigido pelas circumstancias. ${ }^{7}$

Durante a Guerra do Contestado, couberam muitas vezes a Helling as tratativas com o Exército. Sua presença no episódio do ataque às estações, que ocorreu em setembro de 1914, e os telegramas trocados com o General Setembrino de Carvalho durante o conflito, permitem afirmar que Helling permaneceu na região conflagrada, sendo, mais uma vez, "the right man in the right place". Embora os altos representantes da Companhia exercessem inquestionável pressão sobre o Governo Federal e sobre o Exército, no sentido deste proporcionar proteção às estações e à ferrovia, cabia a Helling, devido à proximidade e ao seu conhecimento prático, negociações e informações diretas ao alto comando militar na região. Atesta-o uma série de telegramas 
trocados por Helling com o comandante geral das forças em operação, o General Setembrino de Carvalho. ${ }^{8}$

A chegada da Expedição Setembrino à região proporcionou proteção à ferrovia e suas estações. O General implementou um plano tático que previa o "estrangulamento" do movimento a partir de quatro colunas, Norte, Sul, Leste e Oeste. A esta última cabia a proteção do leito da EFSPRG, restabelecendo seu tráfego e guarnecendo as estações. Em 1915, a Expedição Setembrino foi encerrada, com o esmagamento do reduto de Santa Maria, último grande núcleo de resistência dos rebeldes. Em 1916 permaneceu na região ainda uma força militar, embora bem mais modesta, a cargo do Capitão Vieira da Rosa.

Neste mesmo ano, Robert Helling assumiu importante cargo na Estrada de Ferro Tereza Cristina, que pertencia então à Companhia EFSPRG. Assim descreve Zumblick:

Foi designado para a direção de nossa via férrea em plena Grande Guerra, ou seja, em 1916. Veio da "São Paulo - Rio Grande" onde desfrutou sempre do mais invejável prestígio. Trouxe, ao lado da fama de competente e justo, a alcunha de "Barba de Bode", graças ao cavanhaque alourado que usava. ${ }^{9}$

Seria a promoção um "prêmio" a um Helling que se mostrara fiel a Companhia, mesmo nos mais difíceis momentos? Difícil afirmar. Afinal, ao que indica Zumblick, a transferência para Tubarão (onde ficavam os escritórios da Tereza Cristina) não foi tão tranquila quanto se poderia esperar.

Por ser de nacionalidade alemã, foi vítima, nesta cidade, por várias vezes, de ofensas e hostilidades públicas partidas de determinados elementos locais. [...] Conseguiu, face ao clima de insegurança física em que vivia, permissão para transferir os escritórios desta Estrada para a cidade de Laguna, que o acolheu com fidalguia. ${ }^{10}$

Tais episódios não se encontram narrados nas memórias de Helling.

Helling permaneceu na direção da Estrada de Ferro Tereza Cristina até 28/02/1918. ${ }^{11}$ Nos anos 1920 voltamos a encontrá-lo em Ponta Grossa, ocupando cargo de chefia. ${ }^{12}$ Desconheço a data em que Helling retornou a sua pátria. Em 1931 publicou sua obra, em Berlim. Segundo Trevisan, que não aponta a origem da informação, teria falecido em 1947, alcançando 84 anos.

Rigoroso, severo, justo, ponderado, aventureiro, corajoso, voluntarioso... tais são as representações trazidas por Helling sobre si mesmo ou por aqueles que o conheceram. Segundo Freire, que foi seu subalterno em Ponta Grossa na década de 1920 , 
Minha impressão do chefe não foi lisonjeira. Era alemão, de cavanhaque, fisionomia severa e trato seco, tipicamente prussiano. Entretanto, o tempo e o convívio funcional me fizeram ver a realidade. Muito humano e compreensivo, sua administração era pautada por alto espírito de equidade e justiça, a lembrar o velho refrão: quem vê cara não vê coração. $^{13}$

Uma situação particularmente tensa vivida por Helling foi o episódio dos ataques rebeldes às estações Calmon e São João e à serraria da Lumber, durante a Guerra do Contestado. Este acontecimento marcou o momento de maior expansão e violência do movimento, constituindo-se em verdadeiro trauma na memória dos remanescentes. A grande comoção popular provocada pelos ataques deveu-se não apenas a destruição das estações em questão, mas também ao assassinato de grande volume de moradores locais e à morte do Capitão Matos Costa, que chefiava as ínfimas forças militares então presentes na região. Associada aos terríveis ataques dos rebeldes contra Estações da Estrada de Ferro e à serraria Lumber, amplificou a reação por parte da União, apressando o início da Expedição Setembrino. Bastante volumosa é a documentação primária que trata dos ataques às estações de Calmon e São João. Dentre esta documentação, está a narrativa de Helling, ainda parcialmente inédita, que proporciona interessante representação sobre o episódio.

\section{O ATAQUE REBELDE}

No início de setembro de 1914 os moradores da região de São João de Cima receberam um apavorante recado: haveria um ataque, quem quisesse sobreviver, que fugisse. O povo em peso deslocou-se à estação ferroviária. Muitos saíam tão somente com a roupa do corpo, embarcando em trens de carga abarrotados nos quais as pessoas quase não conseguiam se mexer. Em 5 de setembro, aproximadamente às 14 horas, os "fanáticos" chegaram à estação Calmon; o telegrafista conseguiu ainda enviar rápida mensagem. ${ }^{14} \mathrm{~A}$ estação, as casas, a madeireira e todo o depósito de madeiras da Lumber Company existente em Calmon ardeu logo em seguida. Um imenso clarão se ergueu, podendo ser percebido desde a estação de São João, a cerca de $27 \mathrm{~km}$ de distância. A serraria ficou completamente destruída, restando apenas os esqueletos das gigantescas máquinas responsáveis pela produção.

Os rebeldes adotaram a prática de extermínio de homens, poupando apenas mulheres e crianças. Entretanto, os mantimentos foram saqueados, e uma parte destes sobreviventes não resistiu à fome. A violência inédita empregada nestes ataques marcou a memória local. ${ }^{15} \mathrm{O}$ agente da estação de Calmon, Adolfo Albach, escondeu-se no mato e conseguiu sobreviver (apesar de ter 
recebido dois tiros), testemunhando o ataque contra os turmeiros da Estrada de Ferro, assassinados impiedosamente. ${ }^{16}$ Calmon foi atacada por homens sob o comando de Chiquinho Alonso, recentemente investido do status de chefe comandante dos redutos.

Os moradores de Calmon tinham como destino Porto União da Vitória, localidade logo atingida pelo mesmo pavor que acometera os fugitivos. Da Estação de São João, também ameaçada, partiram moradores temerosos, que abarrotaram o trem de inspeção enviado pela Estrada de Ferro na noite daquele mesmo dia 5 de setembro. ${ }^{17}$ Poucos permaneceram; alguns ainda acreditavam no caráter religioso do movimento e em sua capacidade de dialogar com os líderes dos piquetes. Supostamente o grupo de ataque seria em número de 400 homens, embora alguns falem mesmo em 1000 assaltantes. ${ }^{18}$

A retirada de São João deu-se, em grande parte, através do caminho de ferro. Lotando os trens indiscriminadamente, fossem de passageiros ou de carga, deixaram a região a maior parte dos moradores, "[...] só não saindo os que, por falta de recursos não o podem fazer". ${ }^{19}$ Pode-se constatar, portanto, que a EFSPRG não franqueou o transporte a toda a população, mas cobrou normalmente pelas passagens, apesar da situação desesperadora vivida pelos habitantes da região.

São João foi atacada na madrugada ou pela manhã do dia 06 de setembro de 1914. Apenas naquela manhã chegou a Porto União da Vitória o pedido de socorro enviado desde São João. ${ }^{20} \mathrm{O}$ ataque a São João teria sido ainda mais cruel que a investida sobre Calmon. Chefiado por Venuto Baiano, não teria poupado nenhum homem adulto.

Os ataques às estações inseriam-se em um momento de constantes investidas contra algumas vilas da região. Desde julho de 1914 tais ações vinham se acirrando. Canoinhas, por exemplo, começou a ser atacada em 14 de julho, e permaneceu sob fogo cerrado por meses..$^{21}$ Foi “" [...] exatamente no dia 15 de agosto, [que] os jagunços começaram a movimentar-se em todas as direções, num polígono de area superior a 60 leguas"22, e próximo ao final de agosto o Capitão Matos Costa passou a receber alarmantes notícias de ameaças. Esta foi uma fase de ofensiva generalizada:

Os alvos dos ataques eram os principais núcleos "peludos" do planalto: as vilas de Canoinhas, Itaiópolis, Papanduva, Vila Nova do Timbó e Curitibanos; as estações da Estrada de Ferro São Paulo - Rio Grande, as serrarias da Brazil Lumber and Colonization e, no ápice do processo, a cidade de Lages $[\ldots] .{ }^{23}$

Em 27 de agosto Aleixo Gonçalves tomou Papanduva, que foi retomada a 3 de setembro; Itaiópolis foi tomada em 28 de agosto e Rio Negro ameaçada um dia depois. ${ }^{24}$ 


\section{A NARRATIVA DE HELLING}

Os acontecimentos dos ataques rebeldes são objeto de dois capítulos do livro de Helling, intitulados "Os Fanáticos" e "Fanáticos em São João". ${ }^{5}$ Para analisarmos da maneira adequada estas memórias, devemos levar em conta que o texto do imigrante alemão primava por uma auto-representação heróica, além de um discurso fortemente germânico. Outro filtro a ser considerado é sua extrema dedicação à Estrada de Ferro, sendo estes aspectos importantes ao fazermos a crítica da fonte. Nesta época Robert Helling trabalhava como Chefe de Tráfego da EFSPRG em Porto União da Vitória.

O primeiro dos capítulos, "Os Fanáticos", relata suas reações quando do ataque à estação de Calmon, em 05 de setembro de 1914. A estação São João, mais próxima de Porto União da Vitória, recebeu um telegrama do Chefe da Estação de Calmon, tendo repassado a informação a esta. A mensagem era dramática: " 'Fanáticos aqui, eu ...' E nenhuma palavra a mais". ${ }^{26} \mathrm{~A}$ partir daí, Helling passa a explicar aos seus leitores o fenômeno do "fanatismo" considerado como um "fenômeno bem peculiar na vida do povo brasileiro", relatando a fé local nos monges de maneira etnocêntrica.

As novidades de Calmon apresentavam perigo. O Chefe de Estação de São João vislumbrava os clarões do incêndio. Após a autorização do Chefe da Estação Central, em Curitiba, Helling montou um trem de serviço para fazer o reconhecimento da linha até Calmon, tentando garantir a segurança do trem de passageiros que deveria partir em seguida.

Nesta viagem o memorialista seguiu até próximo de Calmon. O trem comandado pelo alemão teve como objetivo o recolhimento de mulheres, crianças e trabalhadores que se encontravam nas casas de turma, enquanto um segundo trem, este sim de passageiros, recolheu os desesperados remanescentes de São João. ${ }^{27}$ Helling dá a entender que nem todos os trabalhadores desejavam retirar-se, pois acreditavam que os rebeldes não os iriam agredir. Como a viagem foi noturna, a visão do incêndio fez-se mais impressionante:

Depois de algum tempo, entramos em uma clareira, a qual distava agora apenas dois quilômetros de Calmon, e aqui víamos o fogo ardente diante de nós. Os feixes de chamas atingiam o alto do céu, e a fumaça negra subia como um enorme fogo sacrificial. A cena era de uma beleza tão horripilante e era tão sublime, que pareceu impressionar até mesmo o maquinista. Pois ele desacelerou com a alavanca do vapor, de modo que a máquina parou depois de pouco tempo. Calados, observávamos o mar de fogo, do qual nos parecia impossível nos aproximarmos e cujo ardor parecia querer nos repelir dali. ${ }^{28}$ 
Após atingir a última casa de turma, recolhendo mulheres e crianças, o trem retornou para Porto União. Ficara, contudo, uma promessa dos rebeldes, que se temia viesse a ser cumprida:

Os Fanáticos nos enviaram, em seu modo costumeiro, uma mensagem, fixando-a a uma vara quebrada e enfiando-a na terra entre os trilhos da ferrovia entre as estações. $\mathrm{O}$ conteúdo desse bilhete dizia mais ou menos o seguinte: "Nós, José Maria, enviados pela graça da Santa Virgem e do São Sebastião a fim de melhorar o mundo e reinstituir a monarquia, avisamos para as pessoas da ferrovia que devem abandoná-la imediatamente; pois, em dois dias, depois que destruirmos São João, iremos em direção a Porto União, o qual também será aniquilado. José Maria." 29

Agudizava-se, portanto, o conflito. Estranhamente Helling afirma que se passaram dois dias entre o ataque a Calmon e São João, quando as demais fontes afirmam que o segundo ataque ocorreu no dia seguinte. Mais do que uma falha da memória, acredito que tenha sido um recurso estilístico, pois sua narrativa sobre o ataque a São João foi feita através da fala da viúva Schena (cujo nome Helling erroneamente escreve Schiena), que fugiu com os filhos a pé até Porto União, ali chegando apenas após a morte de Matos Costa. Para conferir uma continuidade à narrativa, acredito que Helling distorceu a informação cronológica, pois parecia interessar-lhe mais a criação dramática do que o detalhamento histórico.

A viúva foi obrigada a cozinhar para os rebeldes que mataram seu marido, e ouvira deles que a ordem era de matar todo homem acima de 14 anos. Após este ataque, o pavor tomou conta de Porto União da Vitória. Muitos moradores fugiram do local, boa parte em trens. A empresa não franqueou o transporte aos desesperados passageiros: "Quem, de algum modo pôde, viajou de trem, de maneira que a ferrovia fazia um grande negócio com o desagradável incidente". ${ }^{30}$

Com o acirramento do conflito, entra em cena a figura peculiar do Capitão Matos Costa. Este foi o infeliz protagonista do mais dramático episódio associado ao ataque rebelde às estações da Estrada de Ferro, e sua morte marcou a opinião pública da época e a memória local sobre a Guerra do Contestado. Matos Costa ficou guarnecendo a região após o final da expedição Mesquita, juntamente com uma pequena e despreparada força, que possuía cerca de 50 homens apenas. Aguardando o início da Expedição Setembrino ${ }^{31}$, Matos Costa recebeu a notícia do início dos ataques no dia 05 de setembro.

A figura de Matos Costa vem sendo representada de diferentes formas, tanto nas fontes quanto na historiografia. Seria idealista, sonhador, ingênuo? 
Ou impetuoso e arrogante, desprezando os inúmeros avisos sobre os perigos da situação a enfrentar?

O Capitão era um oficial experiente, veterano de campanhas complexas como a Federalista e Canudos. Sua fé de ofício indica um oficial duro e temido. No Contestado, notabilizou-se entre seus pares como um "bravo" muito antes de sua morte. Relata-se que fazia críticas severas aos coronéis e que conseguira desafetos entre eles. Matos Costa teria tentado negociar com os moderados uma saída honrosa e pacífica para o conflito, entre maio e setembro de 1914.32 Em agosto deste ano o militar viajou ao Rio de Janeiro, onde conversou com altas autoridades militares sobre o problema do Contestado. Seu retorno, no final de agosto, foi atropelado pelo recrudescimento do movimento. Mal sabia o Capitão que os moderados haviam caído em desgraça, tendo se imposto um novo comando, extremamente agressivo, chefiado por Chiquinho Alonso. Isso ajuda a explicar sua atitude pouco cuidadosa no embate da estação de São João e sua aparente descrença de que os rebeldes tivessem más intenções para com a população, tanto civil quanto militar. Em torno deste personagem, construiu-se uma série de memórias conflitantes e representações complexas.

Helling irá apresentar o Capitão como um personagem arrogante, que ao avaliar simploriamente o perigo a enfrentar, causara sua própria ruína. Após o ataque à São João, Matos Costa foi ao escritório do chefe de tráfego solicitar um trem para verificar a situação. Assim relata o memorialista sua conversa com o militar:

O próprio Matos Costa não acreditava que as coisas estivessem tão ruins, mesmo assim viajaria para São João com seu escasso pessoal (apenas cinqüenta soldados armados) para conversar com os fanáticos. Eu o adverti que nunca devemos subestimar o inimigo e que os sujeitos, como eu ficara sabendo, estavam armados com Winchesters e Mausers [...]. Ele riu com desprezo e contou que já havia sido informado que os fanáticos queriam atacar; visto que fora sozinho ao acampamento, surgindo de repente no meio deles e, após conversarem educadamente, o deixaram partir sem machucá-lo. ${ }^{33}$

O Chefe de Tráfego sugeriu uma alteração na montagem do trem, para que este pudesse melhor proteger os soldados; contudo a demora prevista de duas horas fez com que Matos Costa desprezasse tais cuidados. Rapidamente o transporte foi preparado.

O trem estava pronto: a locomotiva, um vagão de carga, três de passageiros e um vagão especial da direção da ferrovia, o qual possuía uma grande plataforma de observação aberta. Perguntei novamente ao capitão se ele não queria pôr 
pelo menos a locomotiva atrás do trem, para que pudesse retornar rapidamente em caso de fracasso da expedição, pois o grande limpa-trilhos ou saca-bois, o qual se encontra na frente da locomotiva, arrastaria dormentes e pedras que fossem colocados pelos fanáticos nos trilhos. Mas ele zombou de mim e pediu que fizesse tudo como ele havia pedido. $^{34}$

É bastante provável que a narrativa de Helling tenha exagerado as reações altivas do Capitão, pois recaiu, desde logo, grande suspeita sobre o papel desempenhado pela Estrada de Ferro no episódio. A ênfase em um comando militar descuidado e incapaz de avaliar o perigo poderia isentar o próprio Chefe de Tráfego de uma maior responsabilidade no episódio. Aliás este é com certeza o filtro a ser aplicado na interpretação de todo e qualquer fonte primária sobre a morte de Matos Costa: a busca de culpados pela tragédia e a necessidade de cada narrador em eximir-se da culpa. $\mathrm{O}$ discurso de Helling terá marcantes aproximações com o discurso dos depoentes que foram interrogados no Inquérito Policial Militar, e atribuirá aos descuidos do Capitão a responsabilidade pelo episódio que resultou em sua morte.

Infelizmente para os leitores de Helling, o diretor da Ferrovia não permitiu que ele acompanhasse o trem que levava Matos Costa e seus homens. Entretanto seu colega, o engenheiro Gräml ${ }^{35}$, obteve autorização, e o relato subsequente do alemão possivelmente foi baseado em seus comentários. Além de Matos Costa e seus soldados, cuja aparência surpreendeu Helling (roupas imundas e rasgadas, vários descalços), acompanhavam a viagem de inspeção o próprio Gräml e dois americanos "que queriam observar as coisas". ${ }^{36}$ Os americanos eram dois engenheiros, Kimmel e Dewitt, encarregados da direção da serraria da Lumber em Calmon. ${ }^{37} \mathrm{O}$ comboio militar levava 58 ou 60 praças (os números variam levemente nas fontes), 2 sargentos e o médico tenente Sylla Teixeira da Silva, amigo de Matos Costa.

Os relatos que tratam diretamente da tragédia de São João trazem algumas contradições. Basicamente, o que ocorreu foi simples: a cerca de três quilômetros da estação de São João, o Capitão e boa parte de seus praças desceram do trem para um reconhecimento; tratava-se contudo de uma emboscada e a força foi trucidada, exceto pelos soldados que fugiram no momento do tiroteio. $\mathrm{O}$ trem que os transportava retrocedeu sem ordens, deixando os bravos completamente desprotegidos. Matos Costa permaneceu firme, tombando no serviço do dever e tornando-se um herói. ${ }^{38}$

Dois fortes motivos contribuem para as variações existentes nas fontes. Um deles é a própria confusão reinante em um momento como esse, em que as balas voavam indiscriminadamente sobre os soldados e o trem. E outro é a culpa. O Inquérito Policial Militar sobre a morte de Matos Costa busca culpados, preferencialmente civis. O relato de Gräml, transcrito por Helling, representa-o 
heroicamente lutando contra a covardia do maquinista. Não devemos, portanto, confiar indiscriminadamente em nenhuma destas narrativas; mesmo assim, são a documentação mais próxima do acontecido com que podemos contar.

Vejamos como o episódio é tratado por Helling. Lembremos que sua narrativa é construída a partir do relato dos que acompanharam a expedição, especialmente através do seu amigo Gräml.

Durante o avanço inicial, os soldados pareciam tranquilos e cantavam "melodias monótonas". Quando a visão melhorou, percebendo-se os campos ao longe, encerrou-se a cantoria e os homens prepararam seus revólveres. Em uma picada, um homem a cavalo acenou e gritou para o trem. O maquinista queria parar e informou ao Capitão tratar-se de um fazendeiro e que parecia ter algo importante a dizer. Porém,

O capitão riu ironicamente e disse que não deixaria seu pessoal se inquietar com as bobagens desses ingênuos "bichos do mato". Gräml calou-se. Ele participara da guerra dos Bôeres contra os ingleses e conhecia a tática da guerrilha, mas não quis manifestar nenhuma objeção, ainda mais que os americanos concordaram com o capitão. ${ }^{39}$

E o trem seguiu. Note-se aqui uma discordância importante em relação a outras fontes que abordam o episódio, tais como o Inquérito, o livro de Cleto da Silva e a obra de Peixoto. ${ }^{40}$ Segundo estas, a locomotiva parou, a cerca de $8 \mathrm{~km}$ de São João, tendo havido uma conversa entre o fazendeiro Generoso Xavier e o Capitão Matos Costa. O civil teria tentado preveni-lo sobre o perigo que enfrentava; contudo o militar teria ridicularizado seus temores e afirmado que não iria recuar sem ver de que.

O momento do encontro com os rebeldes é narrado de maneira profundamente dramática e, ao que tudo indica, tendenciosa. Próximo ao quilômetro 315, a uns 3 quilômetros de São João, o Capitão deu o sinal para a parada do trem e ordenou aos soldados que descessem. Formando uma linha de tiro, em breve foram surpreendidos por disparos saídos do meio de arbustos.

Matos Costa teria descido do trem para reconhecimento com cinquenta e poucos homens, ou seja, quase todo o contingente que possuía, afastando-se da locomotiva cerca de 100 metros. A ordem era que o trem o acompanharia lentamente, para não deixar o grupo desguarnecido. Neste momento teria recebido uma descarga no peito, segundo o Inquérito, tendo início o tiroteio.

A narrativa de Helling modifica esta versão. Segundo ele,

[...] o capitão tranqüilamente parado junto ao trem observava seu pessoal. Os americanos estavam na plataforma de observação do último vagão, quando um deles descobriu vultos furtivos passando silenciosamente pelos arbustos e 
disparou seu enorme Colt. Assim que o tiro retumbou uma saraivada do arbusto no outro lado do brejo cortou o silêncio. Dois soldados caíram e se contorceram agonizantes no chão. O capitão esperou tranqüilamente o ataque inimigo parar, sem soltar seu pequeno cachimbo da boca. Os soldados deitaram no chão e começaram a atirar no inimigo invisível que estava escondido atrás dos arbustos. Os americanos saltaram do trem e fugiram pelos trilhos. ${ }^{41}$

Embora as versões destoem parcialmente, a fuga dos americanos é mencionada também por outras fontes primárias. No dia seguinte, 7 de setembro, chegaram a Porto União da Vitória, com as roupas rasgadas pelos espinhos "[...] pela corrida que fizeram [...]" mas sem ferimentos. ${ }^{42}$

O maquinista teria então abandonado seu posto; o foguista, um "mulato de aparência selvagem", tentou fazer o trem retroceder, mas Gräml, heroicamente, o teria obrigado a retornar a linha de tiro. Ao ajudar um ferido, contudo, o alemão percebeu que o trem se colocava em movimento, retrocedendo, e "instintivamente" pulou para dentro do mesmo. Após retroceder uns dez quilômetros, o trem foi parado e constatou-se que os tiros dos "fanáticos" haviam avariado de tal maneira o cano de conduto que levava água até a caldeira que seria impossível retornar. Assim, usando o peso da própria máquina, retrocederam até a estação Nova Galícia. Ali, Gräml teria pego o trem reserva e retornado ao local do tiroteio, onde soldados relataram que a força havia sido quase que completamente dizimada. $\mathrm{O}$ alemão teria recolhido vários soldados, além de cadáveres.

Gräml deixou o homem [um soldado] entrare cautelosamente recolocou o trem em movimento. Depois de mais ou menos um quilômetro o soldado lhe fez um gesto para parar; e com as espingardas preparadas, os poucos soldados foram a uma clareira onde ocorreu a última batalha. Lá estava o capitão e a alguns passos dele os dois suboficiais. O capitão pressionava seu quepe contra o peito e a expressão em seu rosto parecia tranqüila, enquanto as caras dos suboficiais estavam desfiguradas. As armas tinham sumido, com certeza os fanáticos as haviam levado. Não tinham tempo a perder, a qualquer momento poderia surgir dos arbustos as figuras terríveis dos inimigos. Portanto os cadáveres foram pegos e levados ao trem, que ficou parado por quinze minutos. Ainda soou horrivelmente a sirene da locomotiva no silêncio fúnebre da floresta para chamar algum disperso, mas ninguém apareceu - os fanáticos fizeram o trabalho completo. ${ }^{43}$ 
A seguir Helling relata a confusão reinante em Porto União da Vitória, bem como a ânsia por vingança por parte dos soldados remanescentes.

Penso que seja importante debruçar-se um pouco mais detidamente sobre a representação trazida por Helling e algumas divergências em relação a outras fontes. O motivo da parada da locomotiva não fica claro em sua narrativa. Segundo os testemunhos do Inquérito, o Capitão ordenara a parada da máquina há cerca de $1 \mathrm{~km}$ da estação de São João. Gräml sugerira que a parada se desse após uma "valeta" na qual os "jagunços" poderiam se entricheirar, porém o maquinista parou antes da valeta em questão. ${ }^{44}$ Outros testemunhos mencionam que os rebeldes se encontravam escondidos por "matos", "arbustos" ou mesmo "vassourais". ${ }^{45}$

Uma questão interessante seria pensarmos como os rebeldes montaram a emboscada. Para tanto, precisariam saber onde o trem iria parar para reconhecimento. O maquinista deveria parar após os arbustos e, sem motivo aparente, parou antes. A explicação que me parece mais razoável seria de que os rebeldes haviam avariado os trilhos, impedindo a passagem da máquina. Tal informação encontra-se apenas e unicamente em uma entrevista, coletada por Paulo Pinheiro Machado, na qual o Sr. Dario Carneiro, neto de um Coronel da Guarda Nacional, relata que o maquinista parou devido aos trilhos desmanchados. ${ }^{46}$ Esta informação parece ser corroborada pelo telegrama expedido por Helling para a direção da ferrovia, possivelmente no dia 10 de setembro de 1914. Um viajante, chegado da linha além de Calmon, afirmou que a linha estava boa, tendo sido somente em São João três juntas de trilhos arrancadas, dormentes atravessados na via e pedras nos contra trilhos. ${ }^{47}$ Não se esclarece, contudo, se esta ação deu-se no local da emboscada. As outras fontes que tratam da emboscada não mencionam os trilhos avariados.

Tanto o relato do tenente Sylla, contido no Inquérito, quanto a narrativa de Helling, que reproduz as memórias de Gräml, destacam o medo do maquinista e do foguista, que teriam feito o trem recuar apesar das ameaças feitas por ambos. Curiosamente, tanto Sylla quanto Gräml afirmam ter colocado um revólver na cabeça do maquinista, ordenando o retorno à linha de tiro; e também ambos teriam ficado para trás quando o trem retrocedeu, tendo que "pular no degrau do trem", no caso de Gräm148, ou correr para apanhar o último carro, agarrando-se com dificuldade no pega-mão do carro dos praças, no caso de Sylla. ${ }^{49}$ A esta altura a locomotiva já se encontrava avariada, pois fôra atingida no tubo injetor de água.

O que parece bastante claro, em relação a ambas as narrativas, é a concordância sobre as responsabilidades. Neste momento, ambos representavam as maiores autoridades no trem: Gräml, por parte da administração da Estrada de Ferro, e Sylla, por parte das forças militares. Ambos isentam-se, contudo, ao apontar dois subalternos, no caso do primeiro, e dois civis, no caso do segundo, como culpados pelo deslocamento criminoso do trem. 
O outro culpado, representado como inconsequente e intempestivo, seria o próprio Capitão Matos Costa. A Estrada de Ferro, na figura do engenheiro Gräml, ficou isenta de responsabilidades através do Inquérito. Parece claro que a direção da São Paulo - Rio Grande estava muito atenta às consequências do episódio de São João. Culpar seus funcionários significaria, indiretamente, responsabilizar a empresa, que tanto já havia perdido nos últimos dias. Suponho que houve uma certa pressão por parte da Companhia com relação ao assunto. Lembremos ainda que a Expedição Setembrino estava apenas começando, tornando necessária uma forte colaboração da ferrovia aos esforços militares.

A narrativa de Helling está em sintonia com este discurso. Ao defender e valorizar as ações de Gräml, que de certa forma o representava neste episódio, Helling também isenta a Companhia de maiores responsabilidades. Afinal, Gräml teria ordenado uma série de ações que poderiam ter auxiliado a força de Matos Costa, inclusive várias que me parecem duvidosas, como o fato de soar a sirene ao retornar ao local do conflito. Outro fator a observar, além da defesa da Ferrovia, seria o preconceito étnico. Afinal, o foguista, apontado como o primeiro covarde a tentar fazer recuar o trem (o segundo teria sido o maquinista) era um "mulato de aparência selvagem". A super valorização dos elementos germânicos é questão recorrente no livro de Helling. Ao pedir autorização para acompanhar a força até São João, comentara o chefe de tráfego: "Isso era 1914 e nossos ânimos estavam tão instigados pelos feitos dos nossos irmãos heróis da Alemanha na longínqua Europa que também gostaríamos de empreender algo arriscado para manifestar nossa coragem alemã [...]". ${ }^{50}$ Assim, Gräml, como alemão a bordo da máquina, era apontado como o mais correto e valoroso dentre todos, já que os brasileiros era descuidados ou covardes, assim como os americanos, que fugiram ao início do combate.

\section{CONSIDERAÇÕES FINAIS}

Se observarmos o incidente como um todo, veremos que a EFSPRG acumulou perdas materiais bastante elevadas. Embora as estações incendiadas fossem modestas, sua destruição foi completa; a serraria de Calmon também ardeu completamente. Além disso, altas foram as perdas humanas. Vários funcionários da ferrovia, sobretudo modestos turmeiros (trabalhadores de turma responsáveis pela preservação da via permanente), foram vitimados pelos ataques.

Entre dezenove trabalhadores da Estrada de Ferro e os civis e militares, calculou-se em perto de cem as vítimas dos tabaréus rebelados, em sua sanguinosa passagem entre as estações de Calmon e de São João. [...] Os bandoleiros perderam poucos companheiros $\left[\ldots . .{ }^{51}\right.$ 
Em São João assinalou-se que o telegrafista, João de Oliveira, foi vitimado e seu corpo foi enterrado pela viúva Schena. ${ }^{52}$ Alguns trabalhadores da Estrada de Ferro também foram assassinados. E em Calmon, "“...] além do mestre de linhas e de outros muitos empregados da via férrea e da Companhia Lumber, estava ferido o telegrafista da estrada e, degolado o guarda-chaves $[\ldots] " .{ }^{33}$

Helling afirma que, no dia 06 de setembro de 1914, já havia retirado todo o pessoal das estações ameaçadas "há dias" ${ }_{54}$; contudo, o ataque à Calmon no dia anterior provocou várias vítimas entre os trabalhadores da Estação. Já os turmeiros em geral viviam ao redor da ferrovia juntamente com a família, tornando mais difícil sua evacuação.

Após a chegada do batalhão do Cel. Eduardo Sócrates, que veio guarnecer as estações, foi possível fazer um levantamento mais completo e

[...] verificar que no correr da linha, isso até Calmon [partindo de União da Vitória], já haviam sido encontrados 87 cadaveres de moradores e de turmeiros da Estrada de Ferro, resultado dos ataques dos jagunços..$^{55}$

Além dos trabalhadores atacados, também suas famílias sofreram enormemente. Dentre as famílias de retirantes que continuavam a chegar a União da Vitória encontrava-se uma pobre viúva, de origem polonesa, com três filhos pequenos famintos. Um dos filhos, de três anos, morrera de fome em Calmon, “[...] quando ela, a mártir, depois de ver seu marido morto, um turmeiro da estrada, ganhara o mato, receiosa de perecer também, esquecendose de um pedaço de pão para os pequeninos!"'.56

Após o início da Expedição Setembrino, em 16 de setembro, os trens de reconhecimento da via férrea ainda encontraram cadáveres em São João, insepultos e horrivelmente mutilados, que foram imediatamente enterrados pelas forças. ${ }^{57}$

A morte do Capitão Matos Costa configurou-se como um episódio dramático da Guerra do Contestado, tendo ganhado destaque na imprensa e causado pavor nas cidades próximas, em especial Porto União da Vitória. Várias versões se propagaram popularmente sobre os motivos do assassinato. Machado acredita em uma possível luta pela liderança..$^{58}$

É provável que uma crise interna tenha freado o avanço até a cidade de Porto União da Vitória, cuja tomada seria, conforme se acreditava, um dos objetivos dos piquetes. Nesse sentido, a ação de Matos Costa, embora mal sucedida, teria impedido os rebeldes de prosseguir..$^{59} \mathrm{O}$ terror reinante em União da Vitória fez com que a cidade ficasse esvaziada, fugindo os moradores para diferentes destinos. ${ }^{60}$

A narrativa de Robert Helling, embora mereça, como qualquer fonte, uma forte crítica sobre sua intencionalidade, sobre os preconceitos que expressa 
e sobre as armadilhas interpretativas próprias a uma escrita memorialística, caracteriza-se como uma importante documentação acerca do episódio do ataque às estações da EFSPRG e sobre a morte de Matos Costa. Espero que esse artigo possa trazer a público parte da riqueza desta fonte semi-inédita para os estudos sobre o Contestado e para a história social da região.

\section{NOTAS}

${ }^{1}$ HELLING, Robert. 40 Jahre im Innern von Brasilien: Erlebnisse eines Eisenbahningenieurs, von Robert Helling. Berlin: Pyramidenverlag, Dr. Schwarz \& Co., 1931. Tradução em português de Filipe Neckel, Mirien Plarre e Thiago Benitez. Supervisão: Erica Foerthmann Schultz.

2 LE GOFF, Jacques. História e Memória. Campinas: Editora da Unicamp, 1992. p. 424.

3 POLLAK, Michel. Memória e identidade social. Estudos Históricos, Rio de Janeiro, v. 5, n. 10, p. 200-212, p. 204, 1992. Para discussões sobre o fenômeno da memória, vide ainda NORA, Pierre. Entre memória e historia: a problemática dos lugares. Projeto História, São Paulo, v. 10, p. 7-28, 1993.

${ }^{4}$ LISTA DE IMIGRANTES CHEGADOS NO VAPOR CAMPINAS EM 16/05/1887. Disponível em: $<$ http://www.arquivohistoricojoinville.com.br/ListaImigrantes/lista/tudo.htm $>$ Acesso em: 25 jul. 2011.

5 Sobre a EFSPRG consultar, dentre outros: THOMÉ, Nilson. Trem de ferro: história da ferrovia no contestado. 2. ed. Florianópolis: Lunardelli, 1983. KROETZ, Lando. As estradas de ferro de Santa Catarina 1910-1960. Dissertação (Mestrado em História), UFPR, Curitiba, 1975. KROETZ, Lando. As estradas de ferro do Paraná (1880-1940). Tese (Doutorado em História Econômica), USP, São Paulo, 1985. NODARI, Renato. Estrada de ferro São Paulo Rio Grande: causas e conseqüências de sua construção em território catarinense - 1900/1940. Dissertação (Mestrado em Economia), UFRGS, Porto Alegre, 1999. LANNA, Ana Lúcia Duarte. Ferrovias, cidades, trabalhadores (1870-1920). Tese (Livre Docência em História da Arquitetura), USP, São Paulo, 2002. ESPIG, Márcia Janete. Personagens do Contestado: os turmeiros da estrada de ferro São Paulo - Rio Grande (1908-1915). Pelotas: Editora Universitária UFPel, 2011.

${ }^{6}$ FREIRE apud TREVISAN, Edilberto. Visitantes estrangeiros no Paraná. 2 ed. Curitiba: Torre de Papel, 2002. p. 280.

7 KRUGER, Ewaldo. Vencendo rampas... Porto Alegre: Livraria do Globo, 1937. p. 38.

8 Esta documentação pode ser localizada nos arquivos do Centro de Pesquisa e Documentação de História Contemporânea do Brasil (CPDOC), no Rio de Janeiro. TELEGRAMA HELLING AO GENERAL SETEMBRINO DE CARVALHO. Porto União da Vitória, 06/04/1915. TELEGRAMA R. HELLING AO GENERAL SETEMBRINO DE CARVALHO. Porto União da Vitória, 08/04/1915. TELEGRAMA R. HELLING AO GENERAL SETEMBRINO DE CARVALHO. Porto União da Vitória, 09/04/1915.

9 ZUMBLICK, Walter. “Teresa Cristina”: a ferrovia do carvão. Florianópolis: Ed. da UFSC, 1987. p. 96.

${ }^{10}$ Ibidem, p. 96 e 97.

${ }^{11}$ Ibidem, p. 97. 
${ }^{12}$ FREIRE apud TREVISAN, op. cit., p. 279.

${ }^{13}$ Ibidem, p. 279 e 280.

${ }^{14}$ SILVA, Cleto da. Apontamentos históricos de União da Vitória, 1769-1933. União da Vitória: Ed. do Autor, 1933. p. 112. HELLING, op. cit., p. 32.

${ }^{15}$ MACHADO, Paulo Pinheiro. Lideranças do Contestado: a formação e a atuação das chefias caboclas (1912-1916). Campinas: Ed. da Unicamp, 2004. p. 263.

${ }^{16}$ SILVA, op. cit., p. 117.

${ }^{17}$ Ibidem, p. 114.

${ }^{18}$ STULZER, Aurélio. A guerra dos fanáticos (1912 a 1916): a contribuição dos franciscanos. Vila Velha: Vozes, 1982. p. 71.

${ }^{19}$ SILVA, op. cit., p. 114.

${ }^{20}$ PEIXOTO, Demerval. Campanha do Contestado. Curitiba: Fundação Cultural, 1995. p. 159.

${ }^{21}$ MACHADO, op. cit., p. 252.

${ }^{22}$ SOARES, J. O. Pinto. Guerra em sertões brasileiros. Rio de Janeiro: Papelaria Velho, 1931. p. 83.

${ }^{23}$ MACHADO, op. cit., p. 261.

${ }^{24}$ SOARES, op. cit., p. 84.

${ }^{25}$ O capítulo "Os Fanáticos" foi publicado na obra de Trevisan (2002), que traduziu e publicou três capítulos da obra de Helling. Já "Fanáticos em São João" permanece inédito em língua portuguesa. Irei utilizar aqui a tradução realizada pela professora Erica Foerthmann Schultz e seus alunos. Todas as citações do livro referem-se às páginas do original em alemão.

${ }^{26}$ HELLING, op. cit., p. 32.

${ }^{27}$ Ibidem, p. 35.

${ }^{28}$ Ibidem, p. 37.

${ }^{29}$ Ibidem, p. 38.

${ }^{30}$ Ibidem.

${ }^{31}$ PEIXOTO, op. cit., p. 161.

${ }^{32}$ MACHADO, op. cit., p. 249.

${ }^{33}$ HELLING, op. cit., p. 40.

${ }^{34}$ Ibidem, p. 41.

${ }^{35}$ Grafado "Graeml” no Inquérito Policial Militar. Mantive aqui a grafia conforme Helling.

${ }^{36}$ HELLING, op. cit., p. 41.

${ }^{37}$ SILVA, op. cit., p. 115. Peixoto os identifica como o engenheiro residente Zimel e um outro engenheiro da Lumber Colonization, op. cit., p. 159.

${ }^{38}$ Uma análise detalhada deste episódio foi realizada em minha tese de doutoramento. ESPIG, op. cit., p. 233-251.

${ }^{39}$ HELLING, op. cit., p. 42. 
${ }^{40}$ SILVA, op. cit.; PEIXOTO, op. cit.

${ }^{41}$ HELLING, op. cit., p. 42.

${ }^{42}$ SILVA, op. cit., p. 117.

${ }^{43}$ HELLING, op. cit., p. 44.

${ }^{44}$ INQUÉRITO POLICIAL MILITAR referente ao esclarecimento da morte do Major João Teixeira Mattos Costa. União da Victoria, anno de 1914.

${ }^{45}$ SILVA, op. cit., p. 115, HELLING, op. cit., p. 42; PEIXOTO, op. cit., p. 160.

${ }^{46}$ CARNEIRO IN ENTREVISTAS DIVERSAS. In: MACHADO, Paulo Pinheiro. Um estudo sobre as origens sociais e a formação política das lideranças sertanejas do Contestado, 19121916. Tese (Doutorado em História), Unicamp, Campinas, 2001. p. 395-498. p. 415.

${ }^{47}$ TELEGRAMA HELLING, sl., sd. [10 de setembro de 1914?].

${ }^{48}$ HELLING, op. cit., p. 43.

${ }^{49}$ INQUÉRITO, op. cit., p. 8.

${ }^{50}$ HELLING, op. cit., p. 41.

${ }^{51}$ PEIXOTO, op. cit., p. 163 e 164.

${ }^{52}$ TELEGRAMA HELLING, sl., sd. [10 de setembro de 1914?].

${ }^{53}$ PEIXOTO, op. cit., p. 159.

${ }^{54}$ HELLING, op. cit., p. 42.

${ }^{55}$ SILVA, op. cit., p. 121.

${ }^{56}$ Ibidem, p. 119.

${ }^{57}$ CARVALHO, Fernando Setembrino de. Relatório apresentado ao General de Divisão José Caetano de Faria, Ministro da Guerra. Rio de Janeiro: Imprensa Militar, 1916. p. 42.

${ }^{58}$ MACHADO, op. cit., p. 266.

${ }^{59}$ STULZER, op. cit., p. 75.

${ }^{60}$ SILVA, op. cit., p. 116; PEIXOTO, op. cit., p. 161.

Artigo recebido em novembro de 2012. Aceito em dezembro de 2012. 